\title{
Association of Copy Number Variations in Autism Spectrum Disorders: A Systematic Review
}

\author{
Elif Funda Sener \\ Department of Medical Biology, Erciyes University Medical School, 38039 Kayseri, Turkey \\ Correspondence should be addressed to Elif Funda Sener; efefunda@yahoo.com
}

Received 20 August 2014; Revised 9 October 2014; Accepted 27 October 2014; Published 16 November 2014

Academic Editor: Shuhua Xu

Copyright (C) 2014 Elif Funda Sener. This is an open access article distributed under the Creative Commons Attribution License, which permits unrestricted use, distribution, and reproduction in any medium, provided the original work is properly cited.

\begin{abstract}
Autism spectrum disorders (ASDs) are characterized by language impairments, social deficits, and repetitive behaviors. The onset of symptoms occurs by the age of 3 and shows a lifelong persistence. Genetics plays a major role in the etiology of ASD. Except genetics, several potential risk factors (environmental factors and epigenetics) may contribute to ASD. Copy number variations (CNVs) are the most widespread structural variations in the human genome. These variations can alter the genome structure either by deletion or by duplication. CNVs can be de novo or inherited. Chromosomal rearrangements have been detected in 5-10\% of the patients with ASD and recently copy number changes ranging from a few kilobases $(\mathrm{kb})$ to several megabases $(\mathrm{Mb})$ in size have been reported. Recent data have also revealed that submicroscopic CNVs can have a role in ASD, and de novo CNVs seem to be a more common risk factor in sporadic compared with inherited forms of ASD. CNVs are being implicated as a contributor to the pathophysiology of complex neurodevelopmental disorders and they can affect a wide range of human phenotypes including mental retardation (MR), autism, neuropsychiatric disorders, and susceptibility to other complex traits such as HIV, Crohn's disease, and psoriasis. This review emphasizes the major CNVs reported to date in ASD.
\end{abstract}

\section{Introduction to Autism Spectrum Disorders}

Autism spectrum disorders (ASDs) include Asperger syndrome, autism, pervasive developmental disorder not otherwise specified, and childhood disintegrative disorder according to Diagnostic and Statistical Manual of Mental Disorders $\mathrm{V}$ (DSM-V) criteria [1-3]. ASDs, also termed as pervasive developmental disorders (PDDs), are characterized by impairments in reciprocal social interaction and communication with the presence of restricted and repetitive behaviors [4-8]. Many children with autism spectrum disorders also have intellectual disability, and most of them have lifelong disability requiring substantial social and educational support [5]. Autism was firstly described by Kanner in 1968 as a childhood developmental disorder [9]. Although ASDs are known to be highly heritable (90\%), the underlying genetic mechanisms are still largely unknown and ASD affects $~ 1 \%$ of the population [10-14]. Unfortunately ASD is the most heritable disorder but is not a simple disorder and has a complex etiology $[8,15]$. The genetic architecture of ASD comprises a diversity of rare single nucleotide variants, copy number variations (CNVs), chromosomal abnormalities, and common polymorphic variations. Candidate genes that contribute to ASD represent a spectrum of biological pathways including synaptic function and epigenetic mechanisms. Both gene-gene interactions and gene-environment interactions can be explaining the heterogeneity of ASD $[1,2]$. Several studies have showed that there might be approximately 1,000 genes or loci to ASD contribution $[13,16,17]$.

As summarized in Table 1, several genetic syndromes were associated with ASD. Except autism, clinical manifestations of schizophrenia, developmental delay, bipolar disorders, and intellectual disability are diverse and complex and include abnormalities in neuronal excitability, processing of complex information, and behaviors such as anxiety and impaired social interactions. There is a significant overlap in clinical manifestations in these mental disorders, such as impaired cognitive functions, seizures, and language problems. As a result of the studies, there is no clear clinical or 
TABLE 1: The most common genetic syndromes associated with ASD.

\begin{tabular}{ll}
\hline Genetic syndromes & Gene/chromosome region \\
\hline Fragile X Syndrome & FMR1 \\
Rett Syndrome & MECP2 \\
Neurofibromatosis type 1 & NF1 \\
Tuberous sclerosis & TSC1, TSC2 \\
Prader Willi Syndrome & Del paternal allele at \\
& $15 \mathrm{q} 11-\mathrm{q} 13$ \\
Angelman Syndrome & Del/mutation in maternal \\
Smith-Lemli-Opitz Syndrome & UBE3A \\
Smith-Magenis Syndrome & DHCR7 \\
Velocardiofacial/DiGeorge & $22 \mathrm{q} 11.2$ del \\
Syndrome & ARX \\
ARX Syndrome & $P A H$ \\
Untreated phenylketonuria & $S M C 3$ \\
Cornelia de Lange Syndrome & $22 \mathrm{q} 11.2$ dup \\
Ch 22q11 duplication syndrome & $17 \mathrm{p} 11.2$ dup \\
Potocki-Lupski Syndrome & Trisomy of chromosome 21 \\
Down Syndrome &
\end{tabular}

neurobiological distinction between childhood schizophrenia, pervasive developmental disorder, and autism. Also these neurodevelopmental disorders can be included within the allelic spectrum of the same candidate gene. So, these observations strongly suggest that autism, schizophrenia, and intellectual disability may share similar pathogenic pathways and potential candidate genes in the same pathways $[4,18]$.

\section{What Is CNV? How Can We Detect CNVs?}

Structural genomic variations include any genetic variants that alter chromosomal structure such as inversions, translocations, duplications, and deletions. Genomic structural changes, such as gene copy number variations (CNVs), are extremely frequent in the human genome [31]. CNVs were defined as a segment of DNA larger than one kilobase presenting copy number differences by comparison of two or more genomes. Deletions may be heterozygous (in which one of the usual two copies is missing), homozygous (in which both copies are missing), or hemizygous (e.g., Xchromosome deletions in a male patient) [5]. They can change gene dosage, interrupting coding sequences, and influencing neighboring gene regulation so they have a great impact on gene expression and phenotypes [32]. Sometimes they can cause exon shuffling [33]. CNVs contribute significantly to genetic heterogeneity with an estimated $12-15 \%$ of the human genome. Approximately 14,400 CNV loci larger than $1 \mathrm{~kb}$ were identified to date [34]. The mutation rate for CNV (1001000 times) is much higher than for SNP [35]. The locusspecific mutation rates for CNVs have been estimated to be $\sim 100$ to 10,000 times higher than those for nucleotide substitution rates [36]. Multiple studies of large control cohorts have shown that every person carries many copy number changes that are mostly benign $[37,38]$. The most frequent $\mathrm{CNV}$ is less than $1 \mathrm{~kb}$ and $5-10 \%$ people have larger $\mathrm{CNV}$ including $500 \mathrm{~kb}[37,39]$. CNVs are largely composed of deletions and duplications and they can be de novo or inherited. De novo CNVs are more prevalent in sporadic genomic disorders [15]. The first CNV studies were published in the year of $2004[38,39]$. It is possible that $\mathrm{CNV}$ s have an important role in modulating the phenotypic spectrum in single gene, multigenic, or complex diseases and several reports were related in neuropsychiatric diseases (i.e., autism spectrum disorders, schizophrenia, mental retardation, behavioral problems, epilepsy, and bipolar disorder) with specific CNVs [31, 34, 40-42].

Different experimental approaches can reveal specific CNVs. Fluorescence in situ hybridization (FISH) is the first molecular method for detection of submicroscopic genomic CNVs. MLPA (multiplex ligation-dependent probe amplification) is often used as a targeted method to assess copy number differences [43]. Microarray platforms represent a robust and high-resolution method of analysis. These arrays were originally designed for genome-wide genotyping, but they can also be used to detect CNVs. Comparative genomic hybridization $(\mathrm{CGH})$ is another method which can detect copy number changes $[2,26,41]$. Unfortunately, oligonucleotide arrays cannot detect the CNVs smaller than $500 \mathrm{bp}$ [33]. Array-CGH compares copy number of genomic loci between the patients and reference samples. These variations can range from submicroscopic imbalances (deletions or duplications) to an entire chromosome (aneuploidy) [43]. It is difficult to detect short CNVs with these platforms mentioned above.

Next generation sequencing, as a new approach, was being used from 2007; whole-exome sequencing (WES) has emerged as a cost effective and efficient means to identify rare genic SNV (single nucleotide variant) contributing to risk of multiple disorders including ASD $[44,45]$. Next generation sequencing technology was used to detect $<10 \mathrm{~kb} C N V$ with high resolution [33]. New methods have been developed to call CNV from WES data such as exome-hidden Markov model to normalize exome read depth and a hidden Markov model (HMM) to identify exonic CNV from WES data [13].

\section{CNV Studies in ASD}

Earlier studies mainly with simplex families in ASD showed an increased frequency of CNVs. But the evidence from these studies can only characterize some specific CNVs in ASD families with a broad variety of clinical features [1]. Duplications and deletions that affect lots of loci are associated with ASD [15]. Balanced genomic changes, such as translocations and inversions, also contribute to ASD [46]. CNVs with duplication in $15 \mathrm{q} 13$, deletions in $16 \mathrm{p} 11.2$ [11, 27, 47-49], 7q11.23 with Williams Syndrome locus, 22q11.2 with DiGeorge Syndrome locus, and 1q21.1 and 15q11-13 with Prader Willi-Angelman Syndrome locus [21, 49] are reported to date. Inherited duplications in the $15 \mathrm{q} 11$-q13 region have been reported to occur in $\sim 1 \%$ to $3 \%$ of autism cases [40]. According to the genome-wide studies, copy number changes cause alterations in expression levels of genes within CNVs 
[34]. Thus this structural variation may affect gene expression directly by disrupting genes and altering gene dosage or indirectly through a position effect or unmasking of recessive mutations or functional SNPs on the remaining allele. Unlikely, variants occurring in intronic or intergenic regions may have little or no effects on gene expression [28]. Specific chromosomal regions with CNVs are related with ASD except chromosomes 12,19, 20, and 21. Some of these regions (such as chromosomes 1, 15, 16, and 22) are responsible for both ASD and schizophrenia [31]. Besides, multiple large CNV studies have been reported using different methodologies to examine different cohorts and the obtained data have great impact in the field of autism research to date $[11,20,21,26,27,47,50$ 52]. According to large CNV studies, anyone can conclude that several rare de novo and inherited CNVs contribute to autism susceptibility. Additionally de novo CNVs are higher in simplex families than multiplex families (de novo CNVs are 3-5 times higher in ASD families than in controls).

Jacquemont et al. detected de novo CNVs in $24 \%$ of individuals with autism in a genome-wide association screen; one pair of affected siblings showed spontaneous CNVs in NRXN1. These findings may prove useful for guiding selection of appropriate analytic techniques and specific subgroups of autistic cases in future genetic studies [51]. Sebat et al. suggest that de novo CNVs are found much more frequently among pedigrees with only a single case with autism than in multiplex pedigrees. Their study focused on a sample of 264 families, including 118 "simplex" families, 47 "multiplex" families, and 99 control families with no diagnosis of autism. 17 CNVs were confirmed to be de novo in 16 individuals. The majority of these mutations are novel and only the largest of them (all CNVs were $>4 \mathrm{Mb}$ in size) have been reported previously in the literature. According to their data, all of the detected spontaneous CNVs were in different chromosomes (2p, 2q, 3p, 6p, 7p, 10q, 13q, 15q, 16p, 20p, and 22q). Spontaneous CNVs were present in $10 \%$ of affected individuals in sporadic cases, contrasting with substantially lower rates observed in controls (1\%) and autism cases from multiplex families (3\%) [27]. In the same year, another study investigated CNVs in ASD families and the authors concluded that inherited CNVs may increase the autism risk [20]. Cytogenetic chromosome abnormalities are found in $7.4 \%(129 / 1749)$ of ASD cases with a range from $0 \%$ to $54 \%$. Balanced translocations and inversions accounted for $17 \%$ (22/129) of rearrangements. In their study, the rates of the de novo genomic $\mathrm{CNV}$ rearrangements were approximately 7\% [11]. Christian et al. studied 397 unrelated subjects with ASD and 372 controls using a 19K BAC microarray. Fiftyone autism-specific CNVs were identified in 46 of 397 ASD patients with a rate of $11.6 \%$ [26].

Ozgen et al. enrolled four patients who implicate microcephalin $1(M C P H 1)$ in band 8p23.1 and this gene is an ASD susceptibility gene. A girl with a syndromic form of autistic disorder showed that she had a classic inv dup $\operatorname{del}(8)$ (qter-> p23.1::p23.1-> p21.2) containing at least three candidate genes: $\mathrm{MCPH1}$ and DLGAP2 within the $6.9 \mathrm{Mb}$ terminal deletion and NEF3 within the concomitant $14.1 \mathrm{Mb}$ duplication. Three further patients with $M C P H 1$ copy number changes were found using single-nucleotide polymorphism
(SNP) array analysis in a cohort of 54 families with ASD patients. So they revealed that ASD can be a component of the classical inv dup del(8) phenotype and identified changes in copy number of $M C P H 1$ as a susceptibility factor for ASD in the distal short arm of chromosome 8 [53]. Gregory et al. studied 119 probands from multiplex autism families. Their analysis revealed that a genomic deletion containing the oxytocin receptor gene (OXTR) previously implicated in autism was present only in one proband and his mother [19]. Sykes et al. screened 330 families for SNP association and CNVs in SHANK3. They could not detect CNVs or SNP associations in their study group [54]. Cho et al. studied 28 ASD patients and 62 controls by array-CGH method. Two recurrent $\mathrm{CNV}$ regions in this study were found to be significantly associated with autism. Totally $38 \mathrm{CNVs}$ were identified. One is on the $17 \mathrm{p} 11.2$ region $(21.82-21.85 \mathrm{Mb})$. Although there are no known coding genes in this region, $17 \mathrm{p} 11.2$ has been suggested as an autism-related region. The other significantly associated one is on $8 \mathrm{p} 23.1$, which is one of the most recurrently observed copy number changes in their study. The $8 \mathrm{p} 23.1$ region is a well-known site of frequent chromosomal rearrangements. They conclude that decreased dosage of DEFENSIN was found to be a predisposing factor to idiopathic ASD [25]. 262 ASD patients were studied with the Agilent 244K human genome oligonucleotide CGH microarray. According to their results, deletion/duplication on chromosome 15q13.2q13.3 is related with developmental delay, autistic features, or the other neuropsychiatric issues such as attention deficit-hyperactivity disorder, expressive language delay, bipolar or mood disorder, anxiety disorders and/or obsessive-compulsive disorder, and subclinical EEG or MRI abnormalities [55]. 105 autism patients and 267 unrelated healthy controls using Illumina HumanHap300 Beadchips and Illumina Beadstudio analysis software were investigated. They also identified the same or similar genes from 13 published autism susceptibility loci (1q42, 2q31, 2q37, 3q26, 5p15, 7q22, 7q36, 15q11, 17q11, 18q21, 22q11, 22q13, and Xp22). Besides, they suggested that the occurrence of genomic gains and losses of genes associated with glycobiology is an important contributor to the development of ASD [29]. A total of $4187 \mathrm{CNV}$ regions previously identified in HapMap populations were investigated in Fu et al.s study with a different algorithm approach. The mutation rates of 104 (2.5\%) CNV regions were estimated at the order of $10^{-3}$ per generation and these regions were classified as potential hotspots. 49 (47\%) CNV hotspots include human genes, some of which are known to be functional CNV loci and have an important role of $\mathrm{CNV}$ in human health especially in common and complex diseases [56].

In another study, 1461 ASDs were investigated with oligonucleotide-based microarray analysis. Abnormalities were reported as $12.3 \%$ of these cases and the CNVs surveyed were mostly inherited (69\%) among autistic individuals. These abnormalities included alterations in novel candidate genes such as SNTG2, SOX5, HFE, and TRIP38 [23]. The exon array successfully identified six rare de novo autosomal heterozygous CNVs (including 1q21.3, 1q31.3, 2q13, and 3p26.1 locus) present in blood samples out of 99 probands in another 
study. They also detected complex appearing de novo CNVs. Fifteen out of 17 of the complex CNVs were located in common CNV regions [57]. 223 ASD patients were screened with high-resolution whole genome array-based comparative genomic hybridization (array-CGH) to find out gene dose alterations associated with susceptibility to autism. Clinically significant CNVs were identified in 18 individuals (8\%), of whom 9 cases (4\%) had de novo aberrations and 13 cases carried rare inherited CNVs that may increase the risk of developing ASDs [23]. Using Affymetrix 500K arrays a heterozygous deletion at chromosome 10p12.1 as a novel CNV locus, was identified at a frequency of $\sim 1.4 \%(6 / 427)$ and was observed to intersect PTCHD3 gene. This deletion was found to be inherited in all ASD cases [58].

In 2012, 696 unrelated ASD cases were examined by arrayCGH. 19.307 CNVs smaller than $100 \mathrm{~kb}$ were detected in ASD group. CIB2, DAPP1, and SAE1 genes were reported as novel ASD candidate genes and all were inherited except for a de novo CNV in the GPHN gene [59]. Holt et al. studied 996 individuals with ASD and 1287 controls, respectively, for potential to generate fusion transcripts. They used an alternative mechanism whereby CNVs combine the $5^{\prime}$ and $3^{\prime}$ ends of two genes, creating a fusion gene. According to this methodology there is no evidence that fusion-gene generating CNVs lead to ASD susceptibility [60]. The highest CNV burden in Menashe et al.'s study was in the 16p11.2 locus. This genomic locus has long been known as a genetic risk factor of ASD. Additionally, they implicated three distinct ASD loci within the 15q11-q13 genomic locus [61]. Matsunami et al. used a custom array to obtain high-quality CNV results on 2,175 children with clinically diagnosed ASD and 5,801 children with normal development as a control group [30]. As a result, they confirmed the association of 31 of 185 published ASD-associated CNVs (including the regions of 1q, 2p, 2q, 3p, 4q, 5q, 6p, 8q, 10q, 12q, 15q, 16p, 17p, 20p, $\mathrm{Xp}$, and $\mathrm{Xq}$ ) in their dataset and they concluded these CNVs may be of clinical relevance in the evaluation of children with ASDs. Krumm et al. hypothesized that small genic inherited CNVs might contribute to sporadic autism and they searched for 411 families affected by sporadic ASD. They discovered a total of 847 transmitted, exonic, rare, autosomal CNVs, including 453 transmitted to probands and 394 transmitted to unaffected siblings. They used exome sequencing data in their study and this method enabled them to explore a smaller CNV landscape largely inaccessible by high-density SNP microarray data [62]. Poultney et al. used whole-exome sequencing in 811 individuals (432 ASD cases of European ancestry and 379 ancestry matched controls) to investigate small (1-30 kb) exonic CNVs. They found rare small deletions in subjects with ASD $(P=0.0037) .1-30 \mathrm{~kb}$ deletions were found in $28 \%$ of cases but only $21 \%$ of controls $(P=0.017)$ indicating that small CNVs could contribute to risk in as much as 7\% of individuals with ASD [13]. Nava et al. screened 194 individuals with ASD for CNVs. A de novo triplication of chromosome 15q11-q12 of paternal origin, a deletion on chromosome 9p24, and a de novo $3 \mathrm{q} 29$ deletion were identified as the cause of the disorder in one individual in 2014 [63]. Finally in one study, 73 ASD probands from Austria were examined to obtain their CNV content. According to their findings, they identified a number of new genes or loci associated with autism, such as GPHN, DLG2, HPCAL1, BDNF-OS, and terminal 21q except several others previously identified such as CDH13, AUTS2, DPP6, NRXN3, SH2B1, and CNTNAP2 [64]. The most studied chromosomal locus and CNVs related with ASD are summarized in Table 2.

\section{MicroRNAs and CNV Association}

MicroRNAs (miRNAs), as a class of small (21-nucleotide long) single stranded RNAs particularly abundant in the brain, are known to regulate gene expression at the transcript level with translational inhibition or mRNA cleavage by binding to the $3^{\prime}$ untranslated region ( $3^{\prime}$ UTR) of target mRNAs $[65,66]$. Polymorphisms in miRNA genes can affect the expression of many downstream-regulated genes. According to cancer research, it is obvious that the expression of miRNA genes can also be modified by CNVs [67]. Abnormalities in the translational control of multiple mRNA targets mediated by each miRNA could lead to the differences in phenotypes observed in ASD cases. Conversely, multiple miRNAs can target the same mRNA leading to convergent phenotypes arising from various $\mathrm{CNV}$ loci [65]. Another new class of RNA is described as large intergenic noncoding RNAs (lincRNAs), thought to be more than 4,000 in the human genome. These RNAs have several activities including Xchromosome inactivation and regulation of gene expression in stem cells, cancer cells, and development. In a case report, a 16-year-old female with a karyotype of 46,XX,t $(2 ; 11)$ (p25.1; p15.1)dn has been revealed. The case with disruptions in LINC00299 gene (long intergenic nonprotein coding RNA 299) has developmental disabilities of varying severity [68].

Recently a new study investigated firstly the genome-wide miRNA content of rare CNVs in schizophrenia. Obtained data demonstrated a genome-wide role for CNVs overlapping miRNAs in the genetic risk of schizophrenia [69]. This study could be a good example of studying CNV-miRNA analysis in other neurodevelopmental disorders. Another research was designed for better understanding the CNV-miRNA relationship in 213 probands with intellectual disability. miRNAs which have brain related functions have been found more prevalent in de novo CNV groups compared to common CNV groups [70]. Except CNV analysis in ASD recently one study focused on the contribution of miRNAs in copy number variable regions towards the development of autism. $11 \%$ of the CNV loci (41 out of 378 ) were shown to harbor miRNAs. Among the total 71 miRNAs, a few were previously reported to be related with autism. This can be accepted as a strong evidence for the role of CNV associated miRNAs in autism and suggested a possible mechanism that will account for the genetic heterogeneity and phenotypic variability of autistic patients [71]. Two miRNAs, hsa-mir-4436b-1 and hsa-mir4436b-2, may be evaluated as strong pathogenic candidates in ASD since they have not been found in CNV s from unaffected individuals in another study [72]. 
TABLE 2: Top CNV loci for ASD susceptibility.

\begin{tabular}{|c|c|c|c|c|c|}
\hline CNV locus & Study design & Patients & CNV type & Candidate gene & References \\
\hline $1 \mathrm{q} 21.1$ & Illumina $1 \mathrm{M}$-single array & $\begin{array}{c}996 \text { ASD } \\
\text { patients } \\
1,287 \text { controls }\end{array}$ & $\begin{array}{l}\text { Deletion- } \\
\text { duplication }\end{array}$ & BCL9 & {$[10]$} \\
\hline $1 \mathrm{q} 21.1$ & Array-CGH & $\begin{array}{l}119 \text { ASD } \\
\text { patients }\end{array}$ & $\begin{array}{c}\text { Deletion- } \\
\text { duplication }\end{array}$ & & {$[19]$} \\
\hline 1q21.1 & Affymetrix $10 \mathrm{~K}$ SNP arrays & $\begin{array}{l}\text { 1,496 ASD } \\
\text { families }\end{array}$ & $\begin{array}{c}\text { Deletion- } \\
\text { duplication }\end{array}$ & & {$[20]$} \\
\hline $2 \mathrm{p} 16.3$ & Affymetrix $10 \mathrm{~K}$ SNP arrays & $\begin{array}{c}\text { 1,496 ASD } \\
\text { families } \\
\end{array}$ & $\begin{array}{c}\text { Deletion- } \\
\text { duplication }\end{array}$ & $N R X N 1$ & {$[20]$} \\
\hline $2 \mathrm{p} 16.3$ & Illumina $1 \mathrm{M}$-single array & $\begin{array}{c}996 \text { ASD } \\
\text { patients } \\
1,287 \text { controls }\end{array}$ & $\begin{array}{l}\text { Deletion- } \\
\text { duplication }\end{array}$ & NRXN1 & {$[10]$} \\
\hline $2 \mathrm{p} 16.3$ & $\begin{array}{l}\text { Illumina HumanHap550 } \\
\text { BeadChip }\end{array}$ & $\begin{array}{c}1,336 \\
\text { ASD patients } \\
1110 \text { controls }\end{array}$ & $\begin{array}{l}\text { Deletion- } \\
\text { duplication }\end{array}$ & NRXN1 & {$[21]$} \\
\hline $2 \mathrm{p} 16.3$ & Array-CGH & $\begin{array}{l}223 \text { ASD } \\
\text { patients }\end{array}$ & $\begin{array}{c}\text { Deletion- } \\
\text { duplication }\end{array}$ & NRXN1 & {$[22]$} \\
\hline $3 \mathrm{p} 26.3$ & Illumina $1 \mathrm{M}$-single array & $\begin{array}{c}996 \\
\text { ASD patients } \\
1,287 \text { controls } \\
\end{array}$ & $\begin{array}{l}\text { Deletion- } \\
\text { duplication }\end{array}$ & CNTN4 & {$[10]$} \\
\hline $3 \mathrm{p} 26.3$ & $\begin{array}{l}\text { Illumina HumanHap550 } \\
\text { BeadChip }\end{array}$ & $\begin{array}{c}\text { 1,336 ASD } \\
\text { patients } \\
1110 \text { controls }\end{array}$ & $\begin{array}{c}\text { Deletion- } \\
\text { duplication }\end{array}$ & CNTN4 & {$[21]$} \\
\hline $3 \mathrm{p} 26.3$ & Array-CGH & $\begin{array}{c}223 \text { ASD } \\
\text { patients }\end{array}$ & $\begin{array}{c}\text { Deletion- } \\
\text { duplication }\end{array}$ & CNTN4 & {$[22]$} \\
\hline $6 \mathrm{q} 26$ & $\begin{array}{l}\text { Illumina HumanHap550 } \\
\text { BeadChip }\end{array}$ & $\begin{array}{c}\text { 1,336 ASD } \\
\text { patients } \\
1110 \text { controls }\end{array}$ & $\begin{array}{l}\text { Deletion- } \\
\text { duplication }\end{array}$ & PARK2 & {$[21]$} \\
\hline $6 \mathrm{q} 26$ & Array-CGH & $\begin{array}{l}223 \text { ASD } \\
\text { patients }\end{array}$ & $\begin{array}{c}\text { Deletion- } \\
\text { duplication }\end{array}$ & PARK2 & {$[23]$} \\
\hline $6 \mathrm{q} 26$ & Illumina 1M-single array & $\begin{array}{c}996 \\
\text { ASD patients } \\
1,287 \text { controls }\end{array}$ & $\begin{array}{c}\text { Deletion- } \\
\text { duplication }\end{array}$ & PARK2 & {$[10]$} \\
\hline $6 \mathrm{q} 26$ & Affymetrix $10 \mathrm{~K}$ SNP arrays & $\begin{array}{c}\text { 1,496 ASD } \\
\text { families }\end{array}$ & $\begin{array}{c}\text { Deletion- } \\
\text { duplication }\end{array}$ & PARK2 & {$[20]$} \\
\hline $7 \mathrm{q} 11.22$ & $\begin{array}{l}\text { Illumina HumanHap550 } \\
\text { BeadChip }\end{array}$ & $\begin{array}{c}1,336 \\
\text { ASD patients } \\
1110 \text { controls } \\
\end{array}$ & Duplication & AUTS2 & {$[21]$} \\
\hline $7 \mathrm{q} 11.22$ & Illumina $1 \mathrm{M}$-single array & $\begin{array}{c}996 \\
\text { ASD patients } \\
1,287 \text { controls } \\
\end{array}$ & Duplication & AUTS2 & {$[10]$} \\
\hline $7 \mathrm{q} 11.22$ & Array-CGH & $\begin{array}{l}96 \text { ASD } \\
\text { patients }\end{array}$ & Duplication & AUTS2 & {$[24]$} \\
\hline $8 \mathrm{p} 23.1$ & Array-CGH & $\begin{array}{c}28 \\
\text { ASD patients } \\
62 \text { controls }\end{array}$ & Deletion & DEFENSIN (DEFA5) & {$[25]$} \\
\hline $15 q 11-q 13$ & Array-CGH & $\begin{array}{c}397 \\
\text { ASD patients } \\
372 \text { controls }\end{array}$ & Duplication & $\begin{array}{l}\text { UBE3A, GABRG3, } \\
\text { GABRB3, GABRA5 }\end{array}$ & {$[26]$} \\
\hline $15 q 11-q 13$ & Illumina $1 \mathrm{M}$-single array & $\begin{array}{c}996 \\
\text { ASD patients } \\
1,287 \text { controls }\end{array}$ & Duplication & $\begin{array}{l}\text { UBE3A, GABRG3, } \\
\text { GABRB3, GABRA5 }\end{array}$ & {$[10]$} \\
\hline
\end{tabular}


TABLE 2: Continued.

\begin{tabular}{|c|c|c|c|c|c|}
\hline CNV locus & Study design & Patients & CNV type & Candidate gene & References \\
\hline $15 q 11-q 13$ & $\begin{array}{l}\text { Illumina HumanHap550 } \\
\text { BeadChip }\end{array}$ & $\begin{array}{l}\text { 1,336 ASD } \\
\text { patients } \\
1110 \text { controls }\end{array}$ & Duplication & & {$[19]$} \\
\hline 15q11-q13 & $\mathrm{CGH}$ & $\begin{array}{c}118 \\
\text { ASD patients } \\
196 \text { controls }\end{array}$ & Duplication & $\begin{array}{l}\text { UBE3A, GABRG3, } \\
\text { GABRB3, GABRA5 }\end{array}$ & [27] \\
\hline 15q11-q13 & $\begin{array}{l}\text { Affymetrix GeneChip } \\
\text { Human Mapping } 500 \mathrm{~K} \\
\text { Array }\end{array}$ & $\begin{array}{c}427 \\
\text { ASD patients } \\
500 \text { controls }\end{array}$ & Duplication & $\begin{array}{l}\text { UBE3A, GABRG3, } \\
\text { GABRB3, GABRA5 }\end{array}$ & {$[11]$} \\
\hline $15 \mathrm{q} 13.3$ & Illumina $1 \mathrm{M}$-single array & $\begin{array}{c}996 \\
\text { ASD patients } \\
1,287 \text { controls } \\
\end{array}$ & Deletion & CHRNA7 & {$[10]$} \\
\hline $15 \mathrm{q} 13.3$ & Array-CGH & $\begin{array}{l}119 \text { ASD } \\
\text { patients }\end{array}$ & Deletion & CHRNA7 & {$[19]$} \\
\hline $15 \mathrm{q} 13.3$ & Array-CGH & $\begin{array}{l}223 \text { ASD } \\
\text { patients }\end{array}$ & Deletion & CHRNA7 & {$[22]$} \\
\hline 16p11.2 & $\mathrm{CGH}$ & $\begin{array}{c}118 \\
\text { ASD patients } \\
196 \text { controls }\end{array}$ & $\begin{array}{l}\text { Deletion- } \\
\text { duplication }\end{array}$ & $A 2 B P 1$ & {$[27]$} \\
\hline $16 \mathrm{p} 11.2$ & $\begin{array}{l}\text { Affymetrix GeneChip } \\
\text { Human Mapping } 500 \mathrm{~K} \\
\text { Array }\end{array}$ & $\begin{array}{c}427 \\
\text { ASD patients } \\
500 \text { controls } \\
\end{array}$ & $\begin{array}{l}\text { Deletion- } \\
\text { duplication }\end{array}$ & & [11] \\
\hline 16p11.2 & $\begin{array}{l}\text { Illumina HumanHap550 } \\
\text { BeadChip }\end{array}$ & $\begin{array}{c}1,336 \\
\text { ASD patients } \\
1110 \text { controls } \\
\end{array}$ & $\begin{array}{l}\text { Deletion- } \\
\text { duplication }\end{array}$ & & [19] \\
\hline $16 \mathrm{p} 11.2$ & Illumina $1 \mathrm{M}$-single array & $\begin{array}{c}996 \\
\text { ASD patients } \\
1,287 \text { controls } \\
\end{array}$ & $\begin{array}{l}\text { Deletion- } \\
\text { duplication }\end{array}$ & $M V P, G D P D 3$ & {$[10]$} \\
\hline $16 \mathrm{p} 11.2$ & Array-CGH & $\begin{array}{l}223 \text { ASD } \\
\text { patients }\end{array}$ & $\begin{array}{c}\text { Deletion- } \\
\text { duplication }\end{array}$ & & {$[22]$} \\
\hline 17p11.2 & Array-CGH & $\begin{array}{c}28 \\
\text { ASD patients } \\
62 \text { controls } \\
\end{array}$ & Deletion & & {$[25]$} \\
\hline $22 \mathrm{q} 11.21$ & Affymetrix 10K SNP arrays & $\begin{array}{c}\text { 1,496 ASD } \\
\text { families }\end{array}$ & $\begin{array}{c}\text { Deletion- } \\
\text { duplication }\end{array}$ & & {$[28]$} \\
\hline $22 q 11.21$ & $\begin{array}{l}\text { Affymetrix GeneChip } \\
\text { Human Mapping } 500 \mathrm{~K} \\
\text { Array }\end{array}$ & $\begin{array}{c}427 \\
\text { ASD patients } \\
500 \text { controls } \\
\end{array}$ & $\begin{array}{l}\text { Deletion- } \\
\text { duplication }\end{array}$ & & {$[11]$} \\
\hline $22 \mathrm{q} 11.21$ & $\begin{array}{l}\text { Illumina HumanHap550 } \\
\text { BeadChip }\end{array}$ & $\begin{array}{l}1,336 \\
\text { ASD patients } \\
1110 \text { controls } \\
\end{array}$ & $\begin{array}{l}\text { Deletion- } \\
\text { duplication }\end{array}$ & & {$[21]$} \\
\hline $22 \mathrm{q} 11.21$ & Illumina 1M-single array & $\begin{array}{c}996 \\
\text { ASD patients } \\
1,287 \text { controls } \\
\end{array}$ & $\begin{array}{c}\text { Deletion- } \\
\text { duplication }\end{array}$ & $\begin{array}{c}\text { DiGeorge } \\
\text { Syndrome } \\
\text { region } \\
\end{array}$ & {$[10]$} \\
\hline $22 \mathrm{q} 11.21$ & Array-CGH & $\begin{array}{l}223 \text { ASD } \\
\text { patients }\end{array}$ & $\begin{array}{l}\text { Deletion- } \\
\text { duplication }\end{array}$ & $\begin{array}{l}\text { PI4KA, SNAP29, TBX1, } \\
\text { SLC7A4 SLC25A1, HIC2, } \\
\text { UBE2L3, YPEL1, MAPK1 }\end{array}$ & {$[22]$} \\
\hline $22 \mathrm{q} 13.33$ & Affymetrix $10 \mathrm{~K}$ SNP arrays & $\begin{array}{c}\text { 1,496 ASD } \\
\text { families }\end{array}$ & $\begin{array}{c}\text { Deletion- } \\
\text { duplication }\end{array}$ & SHANK3 & {$[20]$} \\
\hline $22 \mathrm{q} 13.33$ & $\begin{array}{l}\text { Affymetrix GeneChip } \\
\text { Human Mapping 500K } \\
\text { Array }\end{array}$ & $\begin{array}{c}427 \\
\text { ASD patients } \\
500 \text { controls }\end{array}$ & $\begin{array}{l}\text { Deletion- } \\
\text { duplication }\end{array}$ & SHANK3 & {$[11]$} \\
\hline
\end{tabular}


TABLE 2: Continued.

\begin{tabular}{|c|c|c|c|c|c|}
\hline CNV locus & Study design & Patients & CNV type & Candidate gene & References \\
\hline $22 \mathrm{q} 13.33$ & $\begin{array}{l}\text { Illumina HumanHap550 } \\
\text { BeadChip }\end{array}$ & $\begin{array}{c}1,336 \\
\text { ASD patients } \\
1110 \text { controls }\end{array}$ & $\begin{array}{l}\text { Deletion- } \\
\text { duplication }\end{array}$ & SHANK3 & {$[21]$} \\
\hline $22 \mathrm{q} 13.33$ & Illumina $1 \mathrm{M}$-single array & $\begin{array}{c}996 \\
\text { ASD patients } \\
1,287 \text { controls }\end{array}$ & $\begin{array}{l}\text { Deletion- } \\
\text { duplication }\end{array}$ & SHANK3 & {$[10]$} \\
\hline $22 \mathrm{q} 13.33$ & Array-CGH & $\begin{array}{l}223 \text { ASD } \\
\text { patients }\end{array}$ & $\begin{array}{c}\text { Deletion- } \\
\text { duplication }\end{array}$ & SHANK3 & {$[22]$} \\
\hline $22 \mathrm{q} 13.33$ & $\begin{array}{l}\text { Illumina HumanHap300 } \\
\text { Beadchips }\end{array}$ & $\begin{array}{c}105 \\
\text { ASD patients } \\
267 \text { controls }\end{array}$ & $\begin{array}{l}\text { Deletion- } \\
\text { duplication }\end{array}$ & SHANK3 & [29] \\
\hline $\mathrm{Xq} 27.2$ & Illumina iSelect array & $\begin{array}{c}2175 \\
\text { ASD patients } \\
5801 \text { controls } \\
\end{array}$ & Deletion & SPANXC & {$[30]$} \\
\hline $\mathrm{Xq} 28$ & Illumina iSelect array & $\begin{array}{c}2175 \\
\text { ASD patients } \\
5801 \text { controls }\end{array}$ & Deletion & MAGEA8 & {$[30]$} \\
\hline
\end{tabular}

\section{Conclusion}

Copy number variants and microRNAs (miRNAs) are new entities that have changed the level of gene expression and regulation. But little information is known about how CNVs influence miRNA metabolism and regulatory networks [24]. As summarized above, several human studies have established association between structural chromosomal abnormalities and ASD phenotypes suggesting that rare CNVs contribute to ASD risk. ASD is primarily a genetic disorder, but it has been also accepted that it shows genetic heterogeneity. While using the present technologies in CNV studies, we could mention that many more undiscovered CNVs may exist in the human genome, and therefore further studies are expected to improve our knowledge of the distribution and genetic susceptibility of CNVs. The latest advances in autism genetics highlight the complex mechanism of its pathophysiology. Although still in its infancy, the study of CNVs has already enriched our understanding of autism genetics. Additional work will be necessary to clarify the significance of these regions to autism susceptibility. In addition to more traditional explanatory models positing multiplicative effects of common variants, it seems that rare, spontaneous, and highly penetrant mutations may explain a portion of autism cases. Study design with simplex and multiplex families may prove useful for the selection of appropriate analytic techniques and specific subgroups of autism cases in future genetic studies. Despite these advances in our understanding of the likely importance of structural genetic variation in susceptibility to common complex disease, resolution is still limited by technology, and methods to detect copy number differences are unable to detect variation arising as a result of balanced rearrangements [28]. Efforts in molecular technologies with whole genome and whole-exome sequencing, as well as transcriptomic analysis and epigenetic studies, will further explain the mechanisms that contribute to ASD. As the studies go on and with the discovery of new pathways related to ASD will have a major impact on clinical diagnosis and classification of this complex disease.

\section{Conflict of Interests}

The author declares that there is no conflict of interests regarding the publication of this paper.

\section{References}

[1] A. M. Persico and V. Napolioni, "Autism genetics," Behavioural Brain Research, vol. 251, pp. 95-112, 2013.

[2] M. E. Talkowski, E. V. Minikel, and J. F. Gusella, "Autism spectrum disorder genetics: diverse genes with diverse clinical outcomes," Harvard Review of Psychiatry, vol. 2, pp. 65-75, 2014.

[3] American Psychiatric Association, Diagnostic and Statistical Manual of Mental Disorders, American Psychiatric Association, Washington, DC, USA, 5th edition, 2013.

[4] B. H.-Y. Chung, V. Q. Tao, and W. W.-Y. Tso, "Copy number variation and autism: new insights and clinical implications," Journal of the Formosan Medical Association, vol. 113, no. 7, pp. 400-408, 2013.

[5] H. C. Mefford, M. L. Batshaw, and E. P. Hoffman, "Genomics, intellectual disability, and autism," The New England Journal of Medicine, vol. 366, no. 8, pp. 733-743, 2012.

[6] P. Chaste and M. Leboyer, "Autism risk factors: genes, environment, and gene-environment interactions," Dialogues in Clinical Neuroscience, vol. 14, no. 3, pp. 281-292, 2012.

[7] S. Gabriele, R. Sacco, and A. M. Persico, "Blood serotonin levels in autism spectrum disorder: a systematic review and metaanalysis," European Neuropsychopharmacology, vol. 24, no. 6, pp. 919-929, 2014.

[8] M. Laplana, J. L. Royo, A. Aluja, R. López, D. Heine-Sunyer, and J. Fibla, "Absence of substantial copy number differences in a pair of monozygotic twins discordant for features of autism spectrum disorder," Case Reports in Genetics, vol. 2014, Article ID 516529, 9 pages, 2014. 
[9] L. Kanner, "Autistic disturbances of affective contact," Acta Paedopsychiatrica, vol. 35, no. 4, pp. 100-136, 1968.

[10] D. Pinto, A. T. Pagnamenta, L. Klei et al., "Functional impact of global rare copy number variation in autism spectrum disorders," Nature, vol. 466, pp. 368-372, 2010.

[11] C. R. Marshall, A. Noor, J. B. Vincent et al., "Structural variation of chromosomes in autism spectrum disorder," The American Journal of Human Genetics, vol. 82, no. 2, pp. 477-488, 2008.

[12] D. Siniscalco, A. Cirillo, J. J. Bradstreet, and N. Antonucci, "Epigenetic findings in autism: new perspectives for therapy," International Journal of Environmental Research and Public Health, vol. 10, no. 9, pp. 4261-4273, 2013.

[13] C. S. Poultney, A. P. Goldberg, E. Drapeau et al., "Identification of small exonic CNV from whole-exome sequence data and application to autism spectrum disorder," The American Journal of Human Genetics, vol. 93, no. 4, pp. 607-619, 2013.

[14] P. Wang, P. Carrion, Y. Qiao et al., "Genotype-phenotype analysis of 18q12.1-q12.2 copy number variation in autism," European Journal of Medical Genetics, vol. 56, no. 8, pp. 420425, 2013.

[15] S. Banerjee, M. Riordan, and M. A. Bhat, "Genetic aspects of autism spectrum disorders: insights from animal models," Frontiers in Cellular Neuroscience, vol. 8, article 58, 2014.

[16] B. M. Neale, Y. Kou, L. Liu et al., "Patterns and rates of exonic de novo mutations in autism spectrum disorders," Nature, vol. 485, no. 7397, pp. 242-245, 2012.

[17] I. Iossifov, M. Ronemus, D. Levy et al., "De novo gene disruptions in children on the autistic spectrum," Neuron, vol. 74, no. 2, pp. 285-299, 2012.

[18] S. Deutsch, Autism Spectrum Disorders: The Role of Genetics in Diagnosis and Treatment, InTech, 2011.

[19] S. G. Gregory, J. J. Connelly, A. J. Towers et al., "Genomic and epigenetic evidence for oxytocin receptor deficiency in autism," BMC Medicine, vol. 7, article 62, 2009.

[20] P. Szatmari, A. D. Paterson, L. Zwaigenbaum et al., "Mapping autism risk loci using genetic linkage and chromosomal rearrangements," Nature Genetics, vol. 39, no. 3, pp. 319-328, 2007.

[21] J. T. Glessner, K. Wang, and G. Cai, "Autism genome-wide copy number variation reveals ubiquitin and neuronal genes," Nature, vol. 459, no. 7246, pp. 569-573, 2009.

[22] A. Bremer, M. Giacobini, M. Eriksson et al., "Copy number variation characteristics in subpopulations of patients with autism spectrum disorders," American Journal of Medical Genetics B: Neuropsychiatric Genetics, vol. 156, no. 2, pp. 115-124, 2011.

[23] J. A. Rosenfeld, B. C. Ballif, B. S. Torchia et al., "Copy number variations associated with autism spectrum disorders contribute to a spectrum of neurodevelopmental disorders," Genetics in Medicine, vol. 12, no. 11, pp. 694-702, 2010.

[24] I. Cuscó, A. Medrano, B. Gener et al., "Autism-specific copy number variants further implicate the phosphatidylinositol signaling pathway and the glutamatergic synapse in the etiology of the disorder," Human Molecular Genetics, vol. 18, no. 10, pp. 1795-1804, 2009.

[25] S. C. Cho, S.-H. Yim, H. K. Yoo et al., "Copy number variations associated with idiopathic autism identified by whole-genome microarray-based comparative genomic hybridization," Psychiatric Genetics, vol. 19, no. 4, pp. 177-185, 2009.

[26] S. L. Christian, C. W. Brune, J. Sudi et al., "Novel submicroscopic chromosomal abnormalities detected in autism spectrum disorder," Biological Psychiatry, vol. 63, no. 12, pp. 1111-1117, 2008.
[27] J. Sebat, B. Lakshmi, D. Malhotra et al., "Strong association of de novo copy number mutations with autism," Science, vol. 316, no. 5823 , pp. $445-449,2007$.

[28] N. H. Sykes and J. A. Lamb, "Autism: the quest for the genes," Expert Reviews in Molecular Medicine, vol. 9, no. 24, pp. 1-15, 2007.

[29] B. van der Zwaag, L. Franke, M. Poot et al., "Gene-network analysis identifies susceptibility genes related to glycobiology in autism," PLoS ONE, vol. 4, no. 5, Article ID e5324, 2009.

[30] N. Matsunami, D. Hadley, C. H. Hensel et al., "Identification of rare recurrent copy number variants in high-risk autism families and their prevalence in a large ASD population," PLoS ONE, vol. 8, no. 1, Article ID e52239, 2013.

[31] A. K. Merikangas, A. P. Corvin, and L. Gallagher, "Copynumber variants in neurodevelopmental disorders: promises and challenges," Trends in Genetics, vol. 25, no. 12, pp. 536-544, 2009.

[32] H. Lou, S. Li, Y. Yang et al., "A map of copy number variations in Chinese populations," PLoS ONE, vol. 6, no. 11, Article ID e27341, 2011.

[33] E. Shishido, B. Aleksic, and N. Ozaki, "Copy-number variation in the pathogenesis of autism spectrum disorder," Psychiatry and Clinical Neurosciences, vol. 68, no. 2, pp. 85-95, 2014.

[34] P. Carmona-Mora and K. Walz, "Retinoic acid induced 1, RAI1: a dosage sensitive gene related to neurobehavioral alterations including autistic behavior," Current Genomics, vol. 11, no. 8, pp. 607-617, 2010.

[35] J. R. Lupski, "Genomic rearrangements and sporadic disease," Nature Genetics, vol. 39, no. 1, pp. S43-S47, 2007.

[36] A. Itsara, G. M. Cooper, C. Baker et al., "Population analysis of large copy number variants and hotspots of human genetic disease," American Journal of Human Genetics, vol. 84, no. 2, pp. 148-161, 2008.

[37] A. J. Iafrate, L. Feuk, M. N. Rivera et al., "Detection of large-scale variation in the human genome," Nature Genetics, vol. 36, no. 9, pp. 949-951, 2004.

[38] F. Zhang, W. Gu, M. E. Hurles, and J. R. Lupski, "Copy number variation in human health, disease, and evolution," Annual Review of Genomics and Human Genetics, vol. 10, pp. 451-481, 2009.

[39] J. Sebat, B. Lakshmi, J. Troge et al., "Large-scale copy number polymorphism in the human genome," Science, vol. 305, no. 5683, pp. 525-528, 2004.

[40] M. Losh, P. F. Sullivan, D. Trembath, and J. Piven, "Current developments in the genetics of autism: from phenome to genome," Journal of Neuropathology \& Experimental Neurology, vol. 67, no. 9, pp. 829-837, 2008.

[41] L. Bernardini, V. Alesi, S. Loddo et al., "High-resolution SNP arrays in mental retardation diagnostics: how much do we gain?" European Journal of Human Genetics, vol. 18, no. 2, pp. 178-185, 2010.

[42] B. S. Shastry, "Copy number variation and susceptibility to human disorders," Molecular Medicine Reports, vol. 2, no. 2, pp. 143-147, 2009.

[43] A. L. Gropman and M. L. Batshaw, "Epigenetics, copy number variation, and other molecular mechanisms underlying neurodevelopmental disabilities: new insights and diagnostic approaches," Journal of Developmental \& Behavioral Pediatrics, vol. 31, no. 7, pp. 582-591, 2010.

[44] S. J. Sanders, M. T. Murtha, A. R. Gupta et al., "De novo mutations revealed by whole-exome sequencing are strongly 
associated with autism," Nature, vol. 484, no. 7397, pp. 237-241, 2012.

[45] B. J. O'Roak, L. Vives, S. Girirajan et al., "Sporadic autism exomes reveal a highly interconnected protein network of de novo mutations," Nature, vol. 484, no. 7397, pp. 246-250, 2012.

[46] C. R. Marshall and S. W. Scherer, "Detection and characterization of copy number variation in autism spectrum disorder," Methods in Molecular Biology, vol. 838, pp. 115-135, 2012.

[47] L. A. Weiss, Y. Shen, J. M. Korn et al., "Association between microdeletion and microduplication at 16p11.2 and autism," The New England Journal of Medicine, vol. 358, no. 7, pp. 667-675, 2008.

[48] D. Levy, M. Ronemus, B. Yamrom et al., "Rare de novo and transmitted copy-number variation in autistic spectrum disorders," Neuron, vol. 70, no. 5, pp. 886-897, 2011.

[49] S. J. Sanders, A. G. Ercan-Sencicek, V. Hus et al., "Multiple recurrent de novo CNVs, including duplications of the 7q11.23 Williams syndrome region, are strongly associated with autism," Neuron, vol. 70, no. 5, pp. 863-885, 2011.

[50] R. A. Kumar, S. Karamohamed, J. Sudi et al., "Recurrent 16 p11.2 microdeletions in autism," Human Molecular Genetics, vol. 17, no. 4, pp. 628-638, 2008.

[51] M. L. Jacquemont, D. Sanlaville, R. Redon et al., "Array-based comparative genomic hybridisation identifies high frequency of cryptic chromosomal rearrangements in patients with syndromic autism spectrum disorders," Journal of Medical Genetics, vol. 43, no. 11, pp. 843-849, 2006.

[52] E. M. Morrow, S.-Y. Yoo, S. W. Flavell et al., "Identifying autism loci and genes by tracing recent shared ancestry," Science, vol. 321, no. 5886, pp. 218-223, 2008.

[53] H. M. Ozgen, E. van Daalen, P. F. Bolton et al., "Copy number changes of the microcephalin 1 gene (MCPH1) in patients with autism spectrum disorders," Clinical Genetics, vol. 76, no. 4, pp. 348-356, 2009.

[54] N. H. Sykes, C. Toma, N. Wilson et al., "Copy number variation and association analysis of SHANK3 as a candidate gene for autism in the IMGSAC collection," European Journal of Human Genetics, vol. 17, no. 10, pp. 1347-1353, 2009.

[55] D. T. Miller, Y. Shen, L. A. Weiss et al., "Microdeletion/duplication at 15q13.2q13.3 among individuals with features of autism and other neuropsychiatric disorders," Journal of Medical Genetics, vol. 46, no. 4, pp. 242-248, 2009.

[56] W. Fu, F. Zhang, Y. Wang, X. Gu, and L. Jin, "Identification of copy number variation hotspots in human populations," The American Journal of Human Genetics, vol. 87, no. 4, pp. 494504, 2010.

[57] P. B. Celestino-Soper, C. A. Shaw, S. J. Sanders et al., "Use of array CGH to detect exonic copy number variants throughout the genome in autism families detects a novel deletion in TMLHE," Human Molecular Genetics, vol. 20, no. 22, Article ID ddr363, pp. 4360-4370, 2011.

[58] M. M. Ghahramani Seno, B. Y. M. Kwan, K. K. M. Lee-Ng et al., "Human PTCHD3 nulls: rare copy number and sequence variants suggest a non-essential gene," BMC Medical Genetics, vol. 12, article 45, 2011.

[59] A. Prasad, D. Merico, B. Thiruvahindrapuram et al., "A discovery resource of rare copy number variations in individuals with autism spectrum disorder," G3, vol. 2, no. 12, pp. 1665-1685, 2012.

[60] R. Holt, N. H. Sykes, I. C. Conceição et al., "CNVs leading to fusion transcripts in individuals with autism spectrum disorder," European Journal of Human Genetics, vol. 20, no. 11, pp. 1141-1147, 2012.

[61] I. Menashe, E. C. Larsen, and S. Banerjee-Basu, "Prioritization of copy number variation loci associated with autism from AutDB-an integrative multi-study genetic database," PLoS ONE, vol. 8, no. 6, Article ID e66707, 2013.

[62] N. Krumm, B. J. O’Roak, E. Karakoc et al., "Transmission disequilibrium of small CNVs in simplex autism," American Journal of Human Genetics, vol. 93, no. 4, pp. 595-606, 2013.

[63] C. Nava, B. Keren, C. Mignot et al., "Prospective diagnostic analysis of copy number variants using SNP microarrays in individuals with autism spectrum disorders," European Journal of Human Genetics, vol. 22, no. 1, pp. 71-78, 2014.

[64] G. Egger, K. M. Roetzer, A. Noor et al., "Identification of risk genes for autism spectrum disorder through copy number variation analysis in Austrian families," Neurogenetics, vol. 15, no. 2, pp. 117-127, 2014.

[65] V. Vaishnavi, M. Manikandan, B. K. Tiwary, and A. K. Munirajan, "Insights on the functional impact of microRNAs present in autism-associated copy number variants," PLoS ONE, vol. 8, no. 2, Article ID e56781, 2013.

[66] X. Wu, D. Zhang, and G. Li, "Insights into the regulation of human CNV-miRNAs from the view of their target genes," $B M C$ Genomics, vol. 13, no. 1, article 707, 2012.

[67] M. Marcinkowska, M. Szymanski, W. J. Krzyzosiak, and P. Kozlowski, "Copy number variation of microRNA genes in the human genome," BMC Genomics, vol. 12, article 183, 2011.

[68] M. E. Talkowski, G. Maussion, L. Crapper et al., "Disruption of a large intergenic noncoding RNA in subjects with neurodevelopmental disabilities," The American Journal of Human Genetics, vol. 91, no. 6, pp. 1128-1134, 2012.

[69] W. Warnica, D. Merico, G. Costain et al., "Copy number variable MicroRNAs in schizophrenia and their neurodevelopmental gene targets," Biological Psychiatry, 2014.

[70] Y. Qiao, C. Badduke, E. Mercier, S. M. E. Lewis, P. Pavlidis, and E. Rajcan-Separovic, "miRNA and miRNA target genes in copy number variations occurring in individuals with intellectual disability," BMC Genomics, vol. 14, no. 1, article 544, 2013.

[71] M. Marrale, N. N. Albanese, F. Calì, and V. Romano, "Assessing the impact of copy number variants on miRNA Genes in autism by Monte Carlo simulation," PLoS ONE, vol. 9, no. 3, Article ID e90947, 2014.

[72] S. Persengiev, I. Kondova, and R. Bontrop, "Insights on the functional interactions between miRNAs and copy number variations in the aging brain," Frontiers in Molecular Neuroscience, vol. 6, article 32, 2013. 

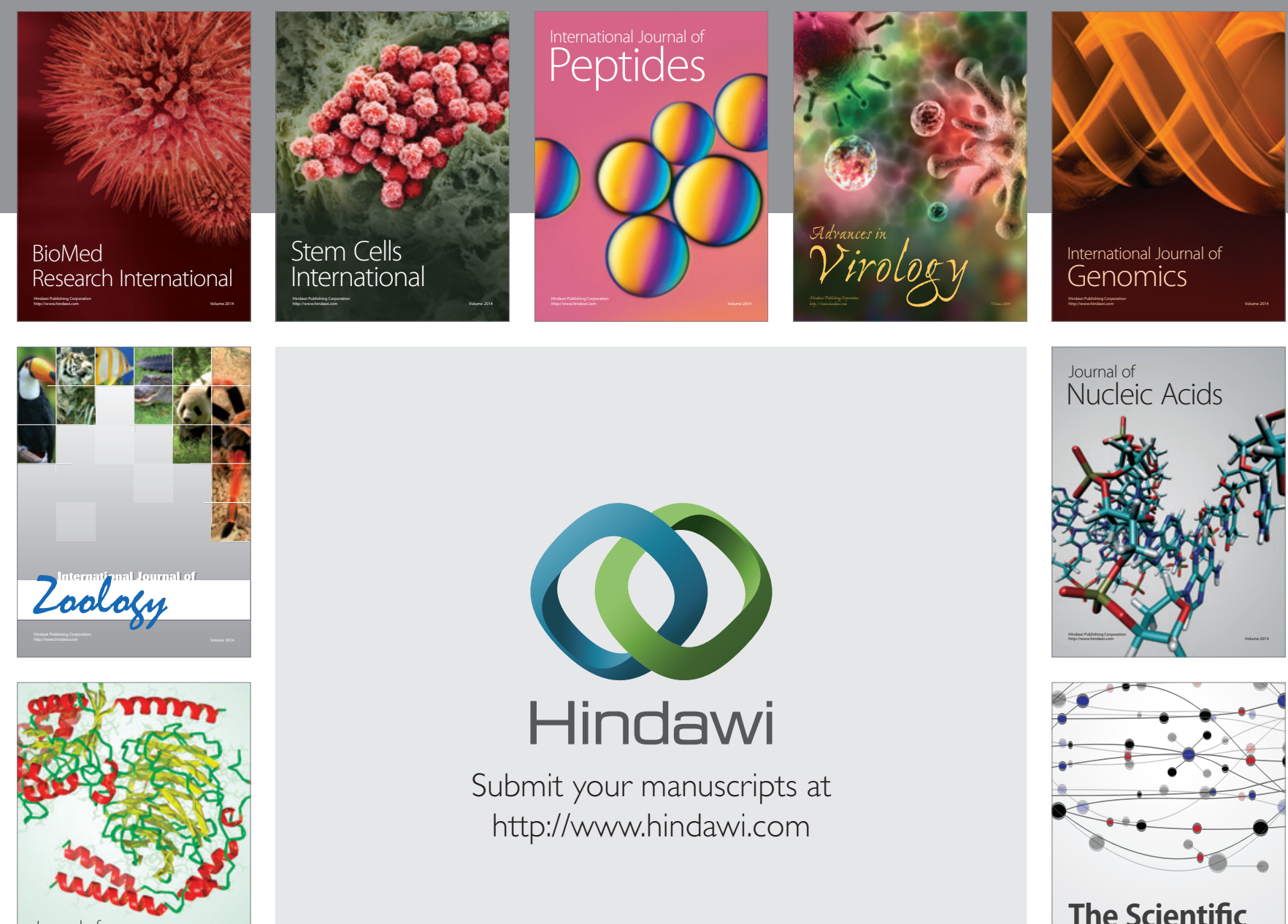

Submit your manuscripts at

http://www.hindawi.com

Journal of
Signal Transduction
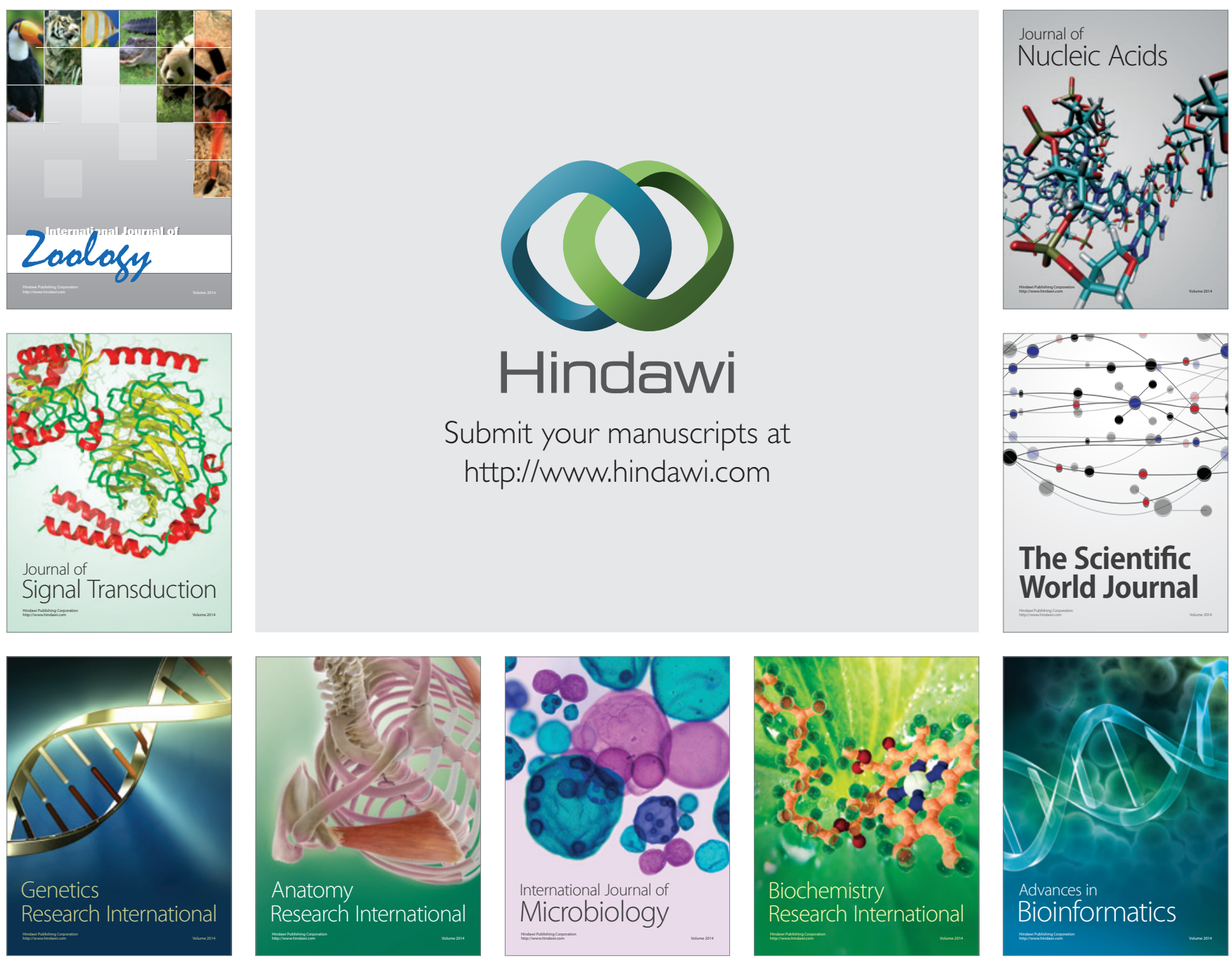

The Scientific World Journal
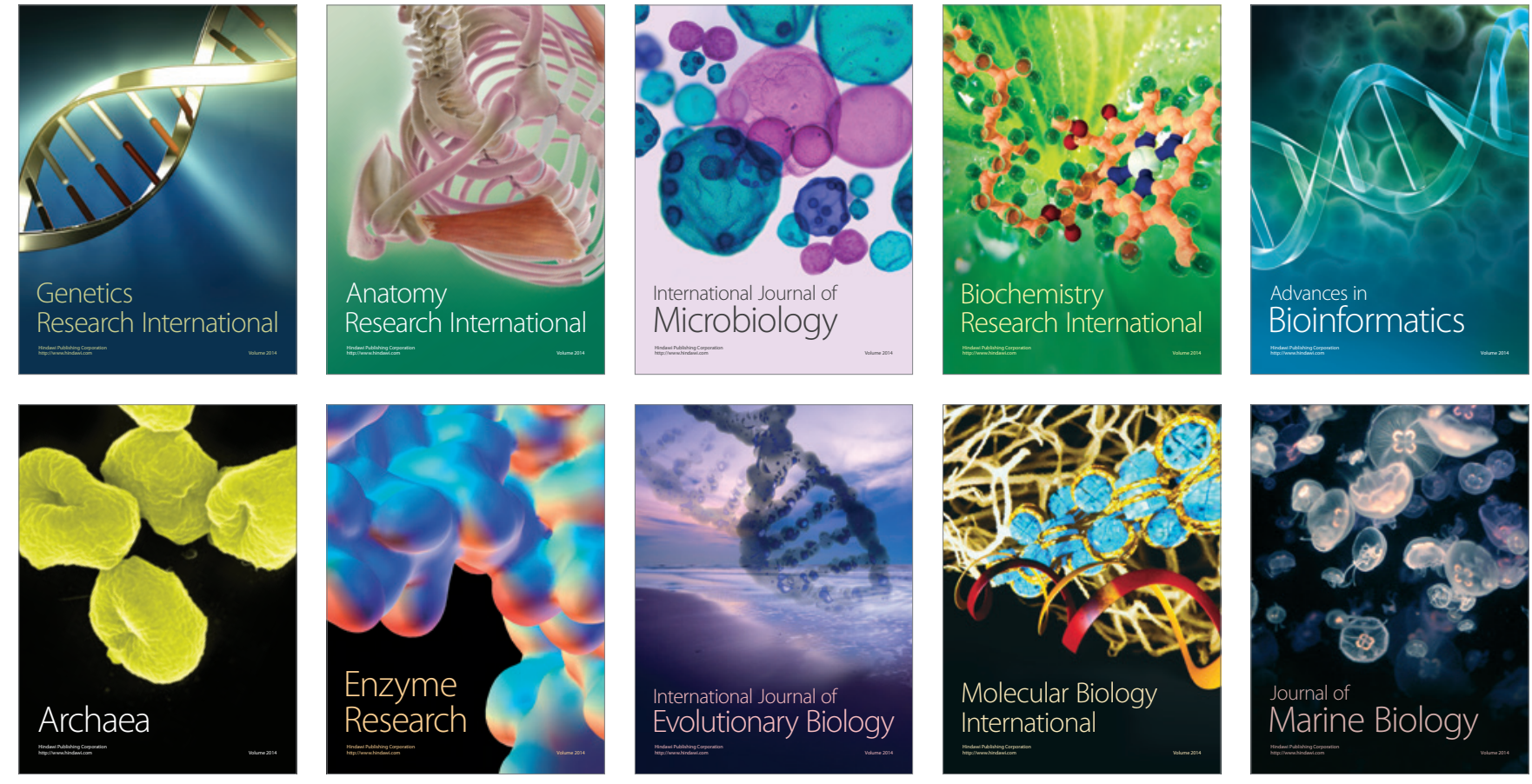